\title{
Physicochemical and Sensory Properties of Pumpkin (Cucurbita moschata D) and Arrowroot (Marantha arundinaceae L) Starch-based Instant Porridge
}

\author{
Agus Slamet $^{\#,+}$, Danar Praseptiangga*, Rofandi Hartanto ${ }^{\# 3}$, Samanhudi \\ ${ }^{\#}$ Doctoral Program of Agricultural Science, Graduate School of Sebelas Maret University (UNS), Surakarta 57126, Central Java, Indonesia \\ Email:"\#lagusumby@yahoo.com \\ ${ }^{+}$Department of Food Science and Technology, Faculty of Agroindustry, University of Mercu Buana Yogyakarta, Yogyakarta, Indonesia \\ *Department of Food Science and Technology, Faculty of Agriculture, Sebelas Maret University (UNS), Surakarta 57126, \\ Central Java, Indonesia \\ Email : ${ }^{\# 2}$ dpraseptiangga@staff.uns.ac.id
}

\author{
^Department of Agrotechnology, Faculty of Agriculture, Sebelas Maret University (UNS), Surakarta 57126, Central Java, Indonesia
}

\begin{abstract}
Pumpkin is a potential source of vitamin A and antioxidant. Arrowroot starch as the source of carbohydrates contains a low glycemic index. However, the utilization of pumpkin and arrowroot starch as the source of food products is still limited. Both ingredients can be processed into nutritious food with practical servings. The objective of the research was to investigate the effect of pumpkin and arrowroot starch ratio and the rotation speed of the drum dryer on the physiochemical properties and the acceptability of the instant porridge. The various ratios of pumpkin and arrowroot starch in the study were 1:1, 2:1, 3:1, 4:1, and 5:1. The process of making instant porridge from pumpkin and arrowroot starch was using a drum dryer with a rotation speed at 1 and 1.5 rpm and a saturated steam pressure at 1 bar. The porridge yield was tested for physiochemical properties and acceptability. The variables of pumpkin to arrowroot starch and the rotation speed of the drum dryer affected the physical and chemical properties, and the acceptability of the instant porridge yielded. Based on amylograph characteristics, the instant porridge had amylograph profile type $C$, except on pumpkin and arrowroot starch in a ratio of 5:1 with drum dryer rotation speed at 1 rpm. The best and most acceptable instant porridge according to the panelists was obtained at the ratio of 5:1 with $1.5 \mathrm{rpm}$ speed.
\end{abstract}

Keywords — instant porridge; pumpkin; arrowroot starch; physicochemical properties.

\section{INTRODUCTION}

Pumpkin (Cucurbita moschata D.) is a type of annual plants from the Cucurbitaceae family. The pumpkin fruit has yellowish-orange skin and flesh, is fibrous and sweeter than the other varieties of pumpkin [1]. Three Cucurbita familia include Cucurbita pepo, Cucurbita moschata and Cucurbita maxima [2]. The three familia contain 0.06-7.4 mg/100 g $\beta$ carotene, 0-7.5 mg/100 g $\alpha$ carotene and 0-17 mg/100 g lutein [3]. Pumpkin can have three to four months of postharvest shelf life. However, once the skin is peeled, pumpkin becomes vulnerable to tenderisation, microbe, color change, and rotting. Storing pumpkin in nitrogen at $4^{\circ} \mathrm{C}$ enhanced the retention of all-E-carotenoids in dehydrated pumpkin [4]. Pumpkin is rich in bioactive compounds, $\beta$ carotene, vitamin $\mathrm{A}$, and tocopherol [5]. Besides vitamin A, pumpkin also contains vitamin $\mathrm{B}_{6}, \mathrm{~K}, \mathrm{C}$, thiamine, and riboflavin.
Pumpkin also provides a good source of nutrition such as carotenoid, vitamin $\mathrm{B}_{2}, \mathrm{C}$, and $\mathrm{E}$; contains low energy and a considerable amount of fiber [6]. Pumpkin is a nutritious and functional vegetable because it is fortified with $\alpha$-tocopherol, $\beta$ carotene, vitamin $\mathrm{C}$, phenol, flavonoid, amino acid, and carbohydrate [5]. Pumpkin flesh contains crude fiber, total fiber, soluble fiber, insoluble fiber as much as 1.06; 19.10; 15.68 and $4.00 \%$, respectively [7]. Polysaccharide in pumpkin has a hypoglycemics activity [8], anticoagulant activity [9], and antitumor [10].

The levels of diphenyl picrylhydrazyl (DPPH) Trolox equivalent and total phenol of fresh pumpkin are 362.47 $\mu \mathrm{mol} / 10 \mathrm{~g}$ and 47.26 gallic acid equivalent (GAE)/10 g, respectively [11]. Carotenoid in pureed pumpkin consists of lutein, $£$ carotene, $\alpha$ carotene, $\beta$ carotene, and cis $\beta$ carotene as much as $0.58 ; 4.21 ; 11.47 ; 17.81$ and $1.98 \mu \mathrm{g} / \mathrm{g}$, respectively [12]. Polysaccharide in pumpkin can cure mice 
with type 2 diabetes by improving the insulin tolerance, lowering blood glucose, total cholesterol, low-density lipoprotein (LDL), and improving high-density lipoprotein (HDL) [13]. Polysaccharide in pumpkin consists of xylose, arabinose, glucose, rhamnose, galactose, and glucuronic acid. Polysaccharide shows an optimum scavenging role as an antioxidant [14]. Supplementing chayote (Sechium edule) as much as $1 \mathrm{ml} / 100 \mathrm{~g}$ body weight can lower the level of total cholesterol, triglyceride, LDL, and increase HDL [15].

Pumpkin can be processed into several products such as jam, jelly, and syrup [12]. Previous research on pumpkin drying used methods such as sun drying [16], and microwave drying [17], combined microwave-hot air drying [18], and microwave vacuum drying [19]. The chemical compositions of pumpkin flour are $6.9 \%$ water content; $2.6 \%$ protein; $4.8 \%$ ash; $8.9 \%$ fibre, and $312.4 \mathrm{mg} / 100 \mathrm{~g}$ total carotene [20], [21]. Pumpkin flour has been distributed for a noodle product [22]. Pumpkin flour is substituted with tempeh flour with a ratio of 33:19 to make instant porridge for babies, resulting in an acceptable instant porridge product according to the panelists [23]. Substituting wheat flour with $2.5 \%$ arrowroot flour results in an organoleptic sensory and an increased carotene level [24]. The pumpkin that is used for baking cake could increase the nutrition value and acceptability of the cake [25]. The bread that is substituted with pumpkin flour and fed to lab mice resulted in a decreasing number of pathogenic bacteria (bifidobacteria) that form lactic in the digestive tract [26]. Processing pumpkin porridge can increase the level of the total phenolic and antioxidant activity [11].

Arrowroot starch is one of the products of arrowroot (Maranta arundinaceae) that contains 16-27\% amylose [27]. Arrowroot is one of the sources of carbohydrate in Indonesia; however, its utilization as a food product is still limited. Most studies on arrowroot focused on carbohydrates, particularly starch [28], [29]. Based on the high level of amylose, arrowroot starch is a potential alternative to ricebased carbohydrate [30]. The degree of polymerization of arrowroot starch reaches $68.3 \%$. The amylopectin chain in arrowroot starch ranges from short to medium length (13-30) with a crystalline structure [31]. The granules of arrowroot starch are oval-shaped with type A gelatinization profile [32]. The size of the starch granule is $7-16 \mu \mathrm{m}$ with a smooth surface [33]. The advantages of arrowroot starch are digestible [28], easy to gelatinize [33], and potential for an edible film [34].

Porridge is a type of nutritious food that is common for breakfast which consists of different cereals or legumes cooked in water or milk. Porridge has a mushy consistency. Another type of porridge is instant porridge that simply needs warm water instead of cooking [35]. Bread made of pumpkin substitution showed increased acceptability compared to wheat flour [36]. To make powder from fruit or vegetables, a drum dryer provides many benefits to the product such as bearing optimum physical properties, efficient, economic, and practical [22]. The drum dryer is suitable for developing instant products [37]. A drum dryer is generally used in the food industry such as baby food, milk, cereal, fruit and vegetable porridge, and starchy products [38]. Processing pumpkin porridge using a drum dryer under $313.54 \mathrm{kPa}$ steam pressure at $1.27 \mathrm{rpm}$ rotation produced pumpkin flour with pleasant physical properties, aroma, and flavor [22]. The higher the temperature in the drum dryer, the faster the cooking process and the lower the water content [39].

Pumpkin and arrowroot starch is the potential nutritious food material as the source of $\beta$ carotene, antioxidants, fiber and calories. The objective of this study was to investigate the physiochemical properties and acceptability of instant porridge made of pumpkin and arrowroot starch.

\section{MATERIALS AND METHODS}

\section{A. Materials}

The primary materials for this research were pumpkin and arrowroot starch. The pumpkins were obtained from Ungaran, Central Java, Indonesia. The characteristics of the pumpkins were at the peak ripening stage (harvested at three months) and showed orange skin and flesh. The pumpkins weighed 8-10 kg each. Arrowroot starch was obtained from the arrowroot starch artisan "Mekar Jaya" in Pajangan, Bantul, Yogyakarta, Indonesia. The equipment used for the research was a drum dryer to make instant porridge made of pumpkin and arrowroot starch. The chemical substances used for the analysis were the pro analysis chemicals.

\section{B. Making Instant Porridge}

Pumpkin was cut into four parts, the seeds and guts scraped. The flesh was chopped using a $2 \times 2 \times 2 \mathrm{~cm}^{3}$ stainless steel knife. The chopped pumpkin and arrowroot starch were weighed for different treatment ratio $(1: 1,2: 1$, $3: 1,4: 1$, and 5:1). Each treatment of $200 \mathrm{ml}$ aquadest was added and blended to obtain a slurry mixture of pumpkin and arrowroot starch with a homogenous and smooth texture. The yielded slurry was then processed using a drum dryer with a rotation speed at 1 and $1.5 \mathrm{rpm}$ with 1 bar pressure. The instant porridge yielded was in the form of flakes with $0.03 \mathrm{~mm}$ thickness which was ground using a grinder and then sieved using an 80 mesh.

\section{Analysis}

The analysis for the experiment consisted of measuring water content with drying method [40], ash content with dry ashing method [40], fat content with a micro Kjeldahl method [40], and starch content with perchloric acid extraction [40]. The level of $\beta$ carotene was measured using a spectrophotometer at a wavelength of $436 \mathrm{~nm}$, and the antioxidant activity was measured using the DPPH method [40]. The level of amylose [41], resistant starch [40], the characteristics of starch granule was analyzed using Scanning Electron Microscopy [31], while yield count [42] oil holding capacity [43]. Bulk density [44], and profile pasting was subject to Rapid Visco Analyzer (RVA) [45]. RVA determined the characteristics of starch paste. As much as $3 \pm 0.01 \mathrm{~g}$ instant porridge was put into an RVA tube that contained $25 \mathrm{ml}$ aquadest. The container was rotated at 160 $\mathrm{rpm}$ at $50^{\circ} \mathrm{C}$ for 20 minutes. The temperature was increased from $50^{\circ} \mathrm{C}$ to $90^{\circ} \mathrm{C}$ for 5 minutes. Once heating became constant, the temperature was lowered to $50^{\circ} \mathrm{C}$ and maintained for 2 minutes. The RVA curve showed peak viscosity (PV), trough/hold viscosity (HV), breakdown (BD), 
final viscosity (FV), setback (SB), pasting temperature (PT), and peak time.

Sensory analysis of the instant porridge included color, aroma, flavor, consistency, and overall evaluation using the hedonic method. The panel consisted of 30 semi-trained panelists who were the students of the Department of Food Science and Technology, Faculty of Agroindustry, University of Mercu Buana Yogyakarta. The 5-point Hedonic scale read 5 (like very much), 4 (like), 3 (neutral), 2 (dislike) and 1 (dislike very much). As much as $20 \mathrm{~g}$ of instant porridge was mixed with $30 \mathrm{~mL}$ hot water $95^{\circ} \mathrm{C} \pm 1$, and stirred to homogenous. The ready instant porridge was served to the panelists, $1 \mathrm{~g}$ each.

\section{Statistical Analysis}

The research used a randomized block design that consisted of two factors namely pumpkin: arrowroot starch ratios $(1: 1,2: 1,3: 1,4: 1$, and 5:1), and the rotation speed of the drum dryer ( 1 and $1.5 \mathrm{rpm})$. The results were analyzed using the $\mathrm{F}$ test, and any significant results would be analyzed further using the Duncan test at $5 \%$ significance.

\section{RESULT AND DISCUSSIONS}

\section{A. Basic Chemical Properties}

The basic ingredients for instant porridge consisted of pumpkin and arrowroot starch. The chemical properties of pumpkin and arrowroot starch are presented in Table 1. The essential components in pumpkin are 16,571.78 $\mu \mathrm{g} / 100 \mathrm{~g} \beta$ carotene; $46.31 \%$ antioxidant activity and $0.06 \%$ phenol. The antioxidant activity expressed in Trolox had the equivalent value in pumpkin Cucurbita maxima, and Cucurbita moschata was $2.61 \pm 0.04$ and $1.92 \pm 0.01$ $\mathrm{mmol} / 100 \mathrm{~g}$, respectively [46]. The level of $\beta$ carotene in pumpkin varied between 1.6 and $45.6 \mathrm{mg} / 100 \mathrm{~g}$ [47]. The main component of arrowroot starch was carbohydrate, particularly starch (78.94\%). Arrowroot starch is the source of energy (320.02 Cal/100 g); therefore, it is the potential source of energy in instant porridge. The crude fiber in pumpkin takes up $2.17 \%$, but in the flesh alone is $1.06 \%$ [7].

TABLE I

CHEMICAL COMPOSITIONS OF BASIC MATERIALS

\begin{tabular}{|c|c|c|}
\hline Components & Pumpkin & $\begin{array}{c}\text { Arrowroot } \\
\text { starch }\end{array}$ \\
\hline Water $(\%)$ & $77.62 \pm 0.35$ & $14.45 \pm 0.06$ \\
\hline Ash (\%) & $1.21 \pm 0.04$ & $1.98 \pm 0.01$ \\
\hline Protein $(\%)$ & $2.12 \pm 0.07$ & $0.45 \pm 0.05$ \\
\hline Fat $(\%)$ & $0.64 \pm 0.04$ & $0.35 \pm 0.02$ \\
\hline Carbohydrate $(\%)$ & $16.23 \pm 0.15$ & $81.80 \pm 0.12$ \\
\hline Starch $(\%)$ & $11.36 \pm 0.12$ & $78.94 \pm 0.69$ \\
\hline Energy $(\mathrm{Cal} / 100 \mathrm{~g})$ & $77.32 \pm 0.27$ & $320.02 \pm 3.39$ \\
\hline Fiber $(\%)$ & $2.17 \pm 0.02$ & $0.95 \pm 0.05$ \\
\hline Non soluble fiber $(\%)$ & $2.39 \pm 0.01$ & $1.85 \pm 0.07$ \\
\hline Soluble fiber $(\%)$ & $0.53 \pm 0.53$ & $0.31 \pm 0.02$ \\
\hline Total fiber $(\%)$ & $2.92 \pm 0.06$ & $2.16 \pm 0.13$ \\
\hline Beta carotene $\mu \mathrm{g} / 100 \mathrm{~g}$ & $16,571.78 \pm 15.02$ & \\
\hline Antioxidant activity (\%) & $46.31 \pm 0.09$ & \\
\hline Phenol $(\%)$ & $0.06 \pm 0.001$ & \\
\hline
\end{tabular}

Table 1 above also shows the level of crude fiber in pumpkin is expectedly due to different harvest time and planting region. Both main components are the potential combination for instant porridge made of pumpkin and arrowroot starch. Porridge is beneficial as the potential source of provitamin A, antioxidant, fiber, and energy. Arrowroot starch was not subjected to analysis of $\beta$ carotene, phenol, and antioxidant activity. It was assumed that arrowroot starch did not contain $\beta$ carotene, phenol, nor antioxidant activity.

\section{B. Physical Properties of Instant Porridge}

The physical properties of instant porridge made of pumpkin and arrowroot starch included yield, bulk density, and water holding capacity (WHC), oil holding capacity $(\mathrm{OHC})$, solubility and viscosity. The physical properties of instant porridge are presented in Table 2.

TABLE II

PhySICAL PROPERTIES OF PUMPKIN AND ARROWROOT STARCH INSTANT PORRIDGE

\begin{tabular}{|c|c|c|c|c|c|c|c|}
\hline $\begin{array}{c}\text { Pumpkin: } \\
\text { arrowroot starch }\end{array}$ & $\begin{array}{c}\text { Rotation } \\
\text { speed drum } \\
\text { drier (rpm) }\end{array}$ & $\begin{array}{l}\text { Yield } \\
(\%)\end{array}$ & $\begin{array}{l}\text { Bulk density } \\
\qquad(\mathrm{g} / \mathrm{ml})\end{array}$ & $\begin{array}{c}\text { WHC } \\
\text { (g water/g } \\
\text { sample) }\end{array}$ & $\begin{array}{c}\text { OHC } \\
\text { (g oil/g } \\
\text { sample) }\end{array}$ & $\begin{array}{l}\text { Solubility } \\
(\%)\end{array}$ & $\begin{array}{l}\text { Viscosity } \\
\quad \text { (cP) }\end{array}$ \\
\hline $1: 1$ & 1 & $18.65 \pm 0.09^{i}$ & $0.31 \pm 0.01^{\mathrm{e}}$ & $9.38 \pm 0.03^{\mathrm{a}}$ & $0.25 \pm 0.01^{\mathrm{a}}$ & $32.54 \pm 0.02^{\mathrm{a}}$ & $14,783.67 \pm 75.51^{\mathrm{j}}$ \\
\hline $2: 1$ & 1 & $18.29 \pm 0.04^{\mathrm{h}}$ & $0.33 \pm 0.01^{\mathrm{de}}$ & $9.65 \pm 0.02^{b}$ & $0.26 \pm 0.01^{\mathrm{ab}}$ & $32.82 \pm 0.04^{\mathrm{b}}$ & $12,959.00 \pm 27.87^{\mathrm{h}}$ \\
\hline $3: 1$ & 1 & $17.59 \pm 0.15^{\mathrm{e}}$ & $0.29 \pm 0.01^{\mathrm{d}}$ & $10.92 \pm 0.04^{\mathrm{d}}$ & $0.26 \pm 0.01^{\mathrm{ab}}$ & $33.67 \pm 0.20^{\mathrm{c}}$ & $11,454.67 \pm 7.57^{f}$ \\
\hline $4: 1$ & 1 & $16.54 \pm 0.11^{\mathrm{c}}$ & $0.27 \pm 0.01^{\mathrm{b}}$ & $11.35 \pm 0.09^{\mathrm{g}}$ & $0.29 \pm 0.01^{\mathrm{c}}$ & $34.72 \pm 0.19^{\mathrm{e}}$ & $8,774.00 \pm 14.17^{\mathrm{d}}$ \\
\hline $5: 1$ & 1 & $15.84 \pm 0.08^{b}$ & $0.27 \pm 0.01^{\mathrm{b}}$ & $12.04 \pm 0.02^{1}$ & $0.37 \pm 0.01^{\mathrm{f}}$ & $36.98 \pm 0.04^{\mathrm{h}}$ & $8,393.00 \pm 19.00^{b}$ \\
\hline $1: 1$ & 1.5 & $18.76 \pm 0.10^{1}$ & $0.33 \pm 0.01^{\mathrm{f}}$ & $10.21 \pm 0.02^{\mathrm{c}}$ & $0.26 \pm 0.01^{\mathrm{ab}}$ & $32.64 \pm 0.03^{\mathrm{a}}$ & $13,495.00 \pm 44.71^{1}$ \\
\hline $2: 1$ & 1.5 & $18.10 \pm 0.05^{\mathrm{g}}$ & $0.31 \pm 0.01^{\mathrm{e}}$ & $10.77 \pm 0.03^{d}$ & $0.26 \pm 0.01^{\mathrm{ab}}$ & $32.95 \pm 0.04^{b}$ & $11,743.00 \pm 55.86^{\mathrm{g}}$ \\
\hline $3: 1$ & 1.5 & $17.83 \pm 0.04^{\mathrm{f}}$ & $0.30 \pm 0.01^{\mathrm{de}}$ & $11.67 \pm 0.04^{\mathrm{f}}$ & $0.29 \pm 0.01^{\mathrm{cd}}$ & $34.07 \pm 0.05^{\mathrm{d}}$ & $9,492.00 \pm 58.88^{\mathrm{e}}$ \\
\hline $4: 1$ & 1.5 & $16.86 \pm 0.04^{\mathrm{d}}$ & $0.28 \pm 0.00^{\mathrm{c}}$ & $11.91 \pm 0.02^{\mathrm{h}}$ & $0.30 \pm 0.01^{\mathrm{d}}$ & $34.94 \pm 0.02^{\mathrm{f}}$ & $8,554.67 \pm 5.03^{\mathrm{c}}$ \\
\hline $5: 1$ & 1.5 & $15.59 \pm 0.04^{\mathrm{a}}$ & $0.25 \pm 0.01^{\mathrm{a}}$ & $12.38 \pm 0.06^{1}$ & $0.31 \pm 0.01^{\mathrm{e}}$ & $36.04 \pm 0.08^{g}$ & $8,233.00 \pm 48.21^{\mathrm{a}}$ \\
\hline
\end{tabular}

1) Yield. Table 2 shows that the more pumpkin used in the porridge, the less yield produced. It was because the higher amount of pumpkin would decrease the total of the solid slurry. The variable of the rotation speed of the drum dryer significantly affected the instant porridge yield $(p<0.05)$. The rotation speed of the drum dryer at $1.5 \mathrm{rpm}$ resulted in a higher yield than that of $1 \mathrm{rpm}$ because the porridge was drier when processed at $1.5 \mathrm{rpm}$ rotation speed than at rpm. Instant pumpkin soup made using the drum dryer produced a higher yield namely $13.30 \%$ [48]. The yield of instant porridge made of pumpkin and arrowroot starch in all treatments ranged between $15.59-18.65 \%$. The yield in this study was higher than that of instant pumpkin soup because the main ingredients consisted of pumpkin and arrowroot starch.

2) Bulk Density: The bulk density of instant porridge across treatments ranged between 0.25 and $0.33 \mathrm{~g} / \mathrm{ml}$. The lowest bulk density was obtained from the treatment of pumpkin and arrowroot starch with a 5:1 ratio with a rotation speed at $1 \mathrm{rpm}$. The highest bulk density was from the 
treatment $1: 1$ at $1.5 \mathrm{rpm}$ speed. The bulk density of pumpkin powder produced from drying temperature of 50, 60, and $70 \mathrm{oC}$ was $0.62 ; 0.86$ and $0.91 \mathrm{~g} / \mathrm{ml}$, respectively [49]. The rotation speed of the drum dryer at $1.5 \mathrm{rpm}$ resulted in instant porridge with a higher bulk density than that at $1 \mathrm{rpm}$. It was because the ingredients remained in the roll of the drum dryer longer than that of the $1.5 \mathrm{rpm}$; therefore, the bulk density was higher, but the water content was lower. Bulk density was correlated with the texture and rehydration in the powder [50]. Bulk density affected the packaging and setting of particle density [51].

3) Water Holding Capacity: The water holding capacity of the instant porridge was 9.38-12.38 g water/g sample. The different ratio of pumpkin and arrowroot starch and the rotational speed of the drum dryer affected water holding capacity. The ingredients at $1.5 \mathrm{rpm}$ rotation speed had a longer contact than at $1 \mathrm{rpm}$, resulting in a dryer instant porridge. The dryer instant porridge had a higher water holding capacity than the less dry one. The higher amount of pumpkin equals a higher water holding capacity because of the hygroscopic characteristic of pumpkin powder. The water holding capacity of pumpkin dried at 50,60 , and $70^{\circ} \mathrm{C}$ was 3.50; 3.00; and $2.33 \mathrm{~g}$ water/g sample, respectively [49]. Water is holding a capacity of pumpkin powder processed by drying at $70^{\circ} \mathrm{C}$ and freeze drying at $-50^{\circ} \mathrm{C}$ was 2.74 and $2.60 \mathrm{~g}$ water/g powder, respectively [43].

4) Oil Holding Capacity: The oil holding capacity of instant porridge ranged between 0.25 and 0.37 . The treatment ratio of pumpkin and arrowroot starch 5:1 showed the highest oil holding capacity with rotation speed at 1 and $1,5 \mathrm{rpm}$. Instant porridge with a higher pumpkin ratio had a higher oil holding capacity. It is because pumpkin powder can absorb the oil better than arrowroot starch. The oil holding capacity of pumpkin porridge was processed with drying at 50,60 , and $70^{\circ} \mathrm{C}$ was $4.42,3.97$, and 3.87 , respectively [49].

5) Solubility: Table 2 shows that the different treatment ratios of pumpkin and arrowroot starch and the rotation speed of the drum dryer affected the solubility of instant porridge. The study showed that the higher the pumpkin proportion at $1.5 \mathrm{rpm}$ rotation speed, the more soluble the instant porridge yielded. The solubility of instant porridge ranged between 36.98 and $32.54 \%$. Instant porridge is hygroscopic-easy to absorb water and dissolve in water. The oil holding capacity of pumpkin powder yielded from drying at 50,60 , and $70^{\circ} \mathrm{C}$ was 54,50 , and 43 , respectively [49].

6) Viscosity: Table 2 shows that the treatment ratio of pumpkin and arrowroot starch and the rotation speed of the drum dryer affected the viscosity of instant porridge. The higher pumpkin proportion at $1.5 \mathrm{rpm}$ rotation speed, the lower the viscosity. Drum dryer rotation speed at $1.5 \mathrm{rpm}$ resulted in the decreasing viscosity compared to that at 1 rpm. The viscosity of instant porridge is affected by the starch component. Starch gelatinization would increase viscosity. Accordingly, starch is generally used as a coagulant [50].

\section{Chemical Components of Instant Porridge}

The chemical components of instant porridge consist of water, ash, fat, protein, starch, amylose, amylopectin and carbohydrate as presented in Table 3.

TABLE III

Chemical Compositions of PUMPKIn AND ARRowroot Starch InSTANT Porridges

\begin{tabular}{|c|c|c|c|c|c|c|c|c|c|}
\hline $\begin{array}{l}\text { Pumpkin: } \\
\text { arrowroot } \\
\text { starch }\end{array}$ & 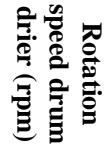 & $\begin{array}{l}\text { Water } \\
(\% \text { db) }\end{array}$ & $\begin{array}{r}\text { Ash } \\
(\% \mathrm{db})\end{array}$ & $\begin{array}{c}\text { Fat } \\
(\% \text { db })\end{array}$ & $\begin{array}{l}\text { Protein } \\
\text { (\% db) }\end{array}$ & $\begin{array}{l}\text { Starch } \\
(\% \text { db })\end{array}$ & $\begin{array}{l}\text { Amylose } \\
\text { (\% db) }\end{array}$ & $\begin{array}{l}\text { Amylo- } \\
\text { pectin } \\
(\% \mathrm{db})\end{array}$ & $\begin{array}{c}\text { Carbohydr } \\
\text { ate } \\
(\% \text { db })\end{array}$ \\
\hline $1: 1$ & 1 & $5.35 \pm 0.04^{\text {cd }}$ & $1.74 \pm 0.02^{\mathrm{b}}$ & $3.81 \pm 0.07^{\mathrm{f}}$ & $2.40 \pm 0.04^{\mathrm{ab}}$ & $51.67 \pm 0.41^{\mathrm{f}}$ & $31.29 \pm 0.04^{i}$ & $68.71 \pm 0.04^{\mathrm{a}}$ & $83.96 \pm 0.75^{\mathrm{b}}$ \\
\hline $2: 1$ & 1 & $5.58 \pm 0.07^{\mathrm{f}}$ & $1.46 \pm 0.04^{\mathrm{a}}$ & $3.05 \pm 0.01^{\mathrm{d}}$ & $2.78 \pm 0.06^{\mathrm{c}}$ & $44.33 \pm 1.54^{\mathrm{e}}$ & $25.42 \pm 0.02^{\mathrm{g}}$ & $74.57 \pm 0.02^{\mathrm{c}}$ & $85.95 \pm 0.12^{\mathrm{d}}$ \\
\hline $3: 1$ & 1 & $5.76 \pm 0.07^{g}$ & $1.84 \pm 0.01^{\mathrm{c}}$ & $3.56 \pm 0.03^{\mathrm{f}}$ & $3.88 \pm 0.02^{\mathrm{de}}$ & $32.75 \pm 0.15^{b}$ & $24.07 \pm 0.04^{\mathrm{e}}$ & $75.93 \pm 0.04^{\mathrm{e}}$ & $84.69 \pm 0.26^{\mathrm{c}}$ \\
\hline $4: 1$ & 1 & $5.39 \pm 0.05^{\mathrm{d}}$ & $2.93 \pm 0.01^{\mathrm{f}}$ & $2.26 \pm 0.02^{\mathrm{a}}$ & $4.11 \pm 0.03^{\mathrm{e}}$ & $31.06 \pm 0.25^{\mathrm{b}}$ & $20.07 \pm 0.03^{c}$ & $79.93 \pm 0.03^{g}$ & $83.65 \pm 0.21^{b}$ \\
\hline $5: 1$ & 1 & $5.35 \pm 0.02^{\text {cd }}$ & $2.59 \pm 0.06^{\mathrm{e}}$ & $2.53 \pm 0.02^{\mathrm{abc}}$ & $4.55 \pm 0.10^{f}$ & $28.07 \pm 0.06^{\mathrm{a}}$ & $18.11 \pm 0.03^{\mathrm{a}}$ & $81.89 \pm 0.03^{\mathrm{i}}$ & $83.04 \pm 0.28^{\mathrm{a}}$ \\
\hline $1: 1$ & 1.5 & $5.17 \pm 0.02^{\mathrm{b}}$ & $1.47 \pm 0.01^{\mathrm{a}}$ & $3.34 \pm 0.02^{\mathrm{e}}$ & $2.11 \pm 0.10^{\mathrm{a}}$ & $52.90 \pm 0.82^{f}$ & $31.27 \pm 0.21^{\mathrm{i}}$ & $68.72 \pm 0.21^{\mathrm{a}}$ & $87.92 \pm 0.17^{\mathrm{e}}$ \\
\hline $2: 1$ & 1.5 & $5.26 \pm 0.01^{\mathrm{c}}$ & $1.52 \pm 0.01^{\mathrm{a}}$ & $2.81 \pm 0.02^{\mathrm{cd}}$ & $2.64 \pm 0.03^{\mathrm{bc}}$ & $45.38 \pm 0.71^{\mathrm{e}}$ & $27.52 \pm 0.09^{\mathrm{h}}$ & $72.48 \pm 0.09^{b}$ & $87.76 \pm 0.21^{\mathrm{e}}$ \\
\hline $3: 1$ & 1.5 & $4.81 \pm 0.06^{\mathrm{a}}$ & $1.59 \pm 0.02^{\mathrm{a}}$ & $2.46 \pm 0.02^{\mathrm{ab}}$ & $3.60 \pm 0.03^{\mathrm{d}}$ & $39.50 \pm 0.81^{\mathrm{d}}$ & $24.42 \pm 0.32^{\mathrm{f}}$ & $75.68 \pm 0.32^{\mathrm{d}}$ & $87.54 \pm 0.06^{\mathrm{e}}$ \\
\hline $4: 1$ & 1.5 & $5.48 \pm 0.03^{\mathrm{e}}$ & $2.07 \pm 0.05^{\mathrm{d}}$ & $2.58 \pm 0.06^{\text {bc }}$ & $4.15 \pm 0.02^{\mathrm{e}}$ & $36.54 \pm 0.25^{\mathrm{c}}$ & $20.37 \pm 0.21^{\mathrm{d}}$ & $79.63 \pm 0.21^{f}$ & $84.73 \pm 0.56^{\mathrm{c}}$ \\
\hline $5: 1$ & 1.5 & $5.81 \pm 0.07^{\mathrm{g}}$ & $2.74 \pm 0.03^{\mathrm{e}}$ & $3.46 \pm 0.03^{\mathrm{e}}$ & $4.57 \pm 0.21^{\mathrm{f}}$ & $31.52 \pm 0.25^{\mathrm{b}}$ & $19.11 \pm 0.10^{b}$ & $80.89 \pm 0.10^{\mathrm{h}}$ & $83.64 \pm 0.34^{b}$ \\
\hline
\end{tabular}

1) Water: The treatment of pumpkin: arrowroot starch affected the water content of instant porridge. The result of this study indicated that the higher the pumpkin ratio, the higher the water content of the porridge. The treatment of the rotational speed of the drum dryer also affected the water content of the porridge. The drum dryer at $1.5 \mathrm{rpm}$ rotation speed produced instant porridge with lower water content than that at $1 \mathrm{rpm}$ rotation. It was because, at $1.5 \mathrm{rpm}$, the ingredients had longer contact with the drum dryer; therefore, the water content was lower. In a study of making pumpkin flour using a drum dryer with rotation speed at 1.5; 1 ; and $1.5 \mathrm{rpm}$, the pumpkin flour contained $4.00-10.02 \%$ water content [22]. The use of a drum dryer with $1 \mathrm{rpm}$ rotation speed and 2 bar steam pressure resulted in $10.66 \%$ water content in dragon fruit/red pitaya (Hylocereus polyrhizus) flour [51]. Rotation speed and steam pressure in the drum dryer affected the water content of the product [52]. The water content of instant porridge made of pumpkin and arrowroot starch in this study was $4.81-6.37 \%$. The low water content in the instant porridge would affect the shelf life: the lower the water content, the lower the water activity $\left(a_{w}\right)$. Food products with lower $a_{w}$ have a longer shelf life.

2) Ash: Table 3 shows that the ash content of instant porridge across treatments ranged between 1.46 and $2.93 \%$. 
The ash content in this study was similar to $3.18 \%$ of pumpkin flour [53]. The Indonesian national Standard requires ash content not to exceed $3.5 \mathrm{~g} / 100 \mathrm{~g}$ [55].

3) Fat: Fat content in instant porridge across treatments in this study ranged between 2.26 and $3.81 \%$. Fat content in treatment with $1.5 \mathrm{rpm}$ drum dryer rotation speed was lower than that with $1 \mathrm{rpm}$ because the ingredients had longer contact which caused more oil in the instant porridge to evaporate. Fat content in the pumpkin porridge is $1.16 \%$ [53], lower than the fat content in the present study because of the different ingredients used. The main ingredient in pumpkin flour is pumpkin, while in instant porridge for this study it was the combined pumpkin and arrowroot starch. Different ash content across treatments was due to the different ratio of pumpkin and arrowroot starch. The Indonesian National Standard requires fat content in instant porridge to not be less than $1.5 \mathrm{~g} / 100 \mathrm{~g}$ and not more than $3.75 \mathrm{~g} / 100 \mathrm{~g}$. The fat content of instant porridge made of pumpkin and arrowroot starch in this study was by the national standard except for the pumpkin-arrowroot ratio 1:1 at $1 \mathrm{rpm}$ rotation speed.

4) Protein: The level of protein in the instant porridge across treatments ranged between 2.11 and $4.57 \%$. The treatment ratio of pumpkin and arrowroot starch significantly affected the level of protein in instant porridge.
The higher pumpkin proportion, the higher protein content compared to the treatment with less pumpkin. Pumpkin flour contained 5.06\% protein [53]. The protein content of instant porridge in this study is lower because the ingredients of the porridge are pumpkin mixed with arrowroot starch.

5) Starch, Amylose, Amylopectin, and Carbohydrate: The level of starch, amylose, amylopectin and carbohydrate of instant porridge tend to be similar. The more pumpkin proportion in the ingredient base the lower the level of starch, amylose, and carbohydrate of the instant porridge

Yield. The percentage of starch, amylose, and amylopectin of the instant porridge was 28.07-52.90\%, 18.11-31.27\%, and $68.72-81.89 \%$, respectively. The level of starch in foodstuff would affect the profile of pasta formulation according to evaluation using the rapid visco analyzer [55]. The level of amylose affected starch gelatinization temperature [50].

\section{Amylograph Properties}

Amylograph properties of instant porridge across different treatments of pumpkin: arrowroot starch ratio with various rotation speeds of the drum dryer is presented in Table 4. The amylograph trend of instant porridge is presented in Fig. 1 and 2.

TABLE IV

AMILOGRAPHY PROPERTIES OF PUMPKIN AND ARROWROOT STARCH INSTANT PORRIDGE

\begin{tabular}{|c|c|c|c|c|c|c|c|c|}
\hline $\begin{array}{c}\text { Pumpkin: } \\
\text { arrowroot } \\
\text { starch }\end{array}$ & $\begin{array}{c}\text { Rotation } \\
\text { speed } \\
\text { drum } \\
\text { drier } \\
(\mathbf{r p m})\end{array}$ & $\begin{array}{c}\text { Gelatinization } \\
\text { Temperature } \\
\left({ }^{\mathbf{C}} \mathbf{C}\right)\end{array}$ & $\begin{array}{c}\text { Peak Viscosity } \\
(\mathbf{R V U})\end{array}$ & $\begin{array}{c}\text { Trough } \\
(\mathbf{R V U})\end{array}$ & $\begin{array}{c}\text { Breakdown } \\
(\mathbf{R V U})\end{array}$ & $\begin{array}{c}\text { Setback } \\
\text { (RVU) }\end{array}$ & $\begin{array}{c}\text { Final } \\
\text { Viscosity } \\
\text { (RVU) }\end{array}$ & $\begin{array}{c}\text { Peak time } \\
\text { (minutus) }\end{array}$ \\
\hline $1: 1$ & 1 & $50.80 \pm 0.05^{\mathrm{e}}$ & $503.00 \pm 1.70^{\mathrm{c}}$ & $314.33 \pm 0.57^{\mathrm{e}}$ & $188.67 \pm 1.15^{\mathrm{c}}$ & $217.67 \pm 0.57^{\mathrm{h}}$ & $493.33 \pm 2.08^{\mathrm{e}}$ & $3.06 \pm 0.02^{\mathrm{a}}$ \\
\hline $2: 1$ & 1 & $50.07 \pm 0.01^{\mathrm{a}}$ & $636.67 \pm 2.80^{\mathrm{e}}$ & $305.67 \pm 2.00^{\mathrm{d}}$ & $333.67 \pm 3.21^{\mathrm{e}}$ & $194.00 \pm 2.08^{\mathrm{g}}$ & $497.33 \pm 1.53^{\mathrm{f}}$ & $3.06 \pm 0.01^{\mathrm{a}}$ \\
\hline $3: 1$ & 1 & $50.21 \pm 0.01^{\mathrm{c}}$ & $1,509.00 \pm 1.00^{\mathrm{i}}$ & $498.00 \pm 2.00^{\mathrm{h}}$ & $1013.33 \pm 3.05^{\mathrm{i}}$ & $220.00 \pm 2.00^{\mathrm{c}}$ & $719.00 \pm 2.00^{\mathrm{i}}$ & $3.06 \pm 0.01^{\mathrm{a}}$ \\
\hline $4: 1$ & 1 & $50.16 \pm 0.01^{\mathrm{b}}$ & $965.00 \pm 1.00^{\mathrm{g}}$ & $442.67 \pm 8.73^{\mathrm{g}}$ & $537.00 \pm 3.68^{\mathrm{g}}$ & $184.67 \pm 8.74^{\mathrm{f}}$ & $619.00 \pm 2.65^{\mathrm{h}}$ & $3.20 \pm 0.01^{\mathrm{d}}$ \\
\hline $5: 1$ & 1 & - & $71.00 \pm 0.00^{\mathrm{a}}$ & $48.00 \pm 1.00^{\mathrm{a}}$ & $25.67 \pm 1.53^{\mathrm{a}}$ & $13.00 \pm 1.00^{\mathrm{a}}$ & $61.67 \pm 1.53^{\mathrm{a}}$ & $3.13 \pm 0.01^{\mathrm{b}}$ \\
\hline $1: 1$ & 1.5 & $50.47 \pm 0.02^{\mathrm{d}}$ & $1,321.00 \pm 1.00^{\mathrm{h}}$ & $445.33 \pm 0.57^{\mathrm{g}}$ & $878.33 \pm 1.52^{\mathrm{h}}$ & $246.00 \pm 0.57^{\mathrm{i}}$ & $690.00 \pm 2.00^{\mathrm{i}}$ & $3.06 \pm 0.01^{\mathrm{a}}$ \\
\hline $2: 1$ & 1.5 & $51.56 \pm 0.01^{\mathrm{f}}$ & $597.33 \pm 1.15^{\mathrm{d}}$ & $286.00 \pm 5.29^{\mathrm{c}}$ & $312.00 \pm 2.00^{\mathrm{d}}$ & $167.67 \pm 5.29^{\mathrm{e}}$ & $457.00 \pm 1.53^{\mathrm{d}}$ & $3.26 \pm 0.01^{\mathrm{d}}$ \\
\hline $3: 1$ & 1.5 & $50.21 \pm 0.01^{\mathrm{c}}$ & $595.33 \pm 0.57^{\mathrm{d}}$ & $288.33 \pm 2.08^{\mathrm{c}}$ & $308.00 \pm 2.00^{\mathrm{d}}$ & $146.33 \pm 2.08^{\mathrm{c}}$ & $436.67 \pm 2.00^{\mathrm{c}}$ & $3.13 \pm 0.01^{\mathrm{b}}$ \\
\hline $4: 1$ & 1.5 & $79.72 \pm 0.02^{\mathrm{h}}$ & $768.33 \pm 2.80^{\mathrm{f}}$ & $368.67 \pm 1.53^{\mathrm{f}}$ & $405.67 \pm 1.53^{\mathrm{f}}$ & $158.67 \pm 1.53^{\mathrm{d}}$ & $526.00 \pm 2.00^{\mathrm{f}}$ & $3.06 \pm 0.01^{\mathrm{a}}$ \\
\hline $5: 1$ & 1.5 & $76.84 \pm 0.01^{\mathrm{g}}$ & $245.00 \pm 1.00^{\mathrm{b}}$ & $157.33 \pm 2.31^{\mathrm{b}}$ & $88.00 \pm 2.00^{\mathrm{b}}$ & $88.67 \pm 2.30^{\mathrm{b}}$ & $243.33 \pm 1.53^{\mathrm{b}}$ & $6.20 \pm 0.01^{\mathrm{e}}$ \\
\hline
\end{tabular}

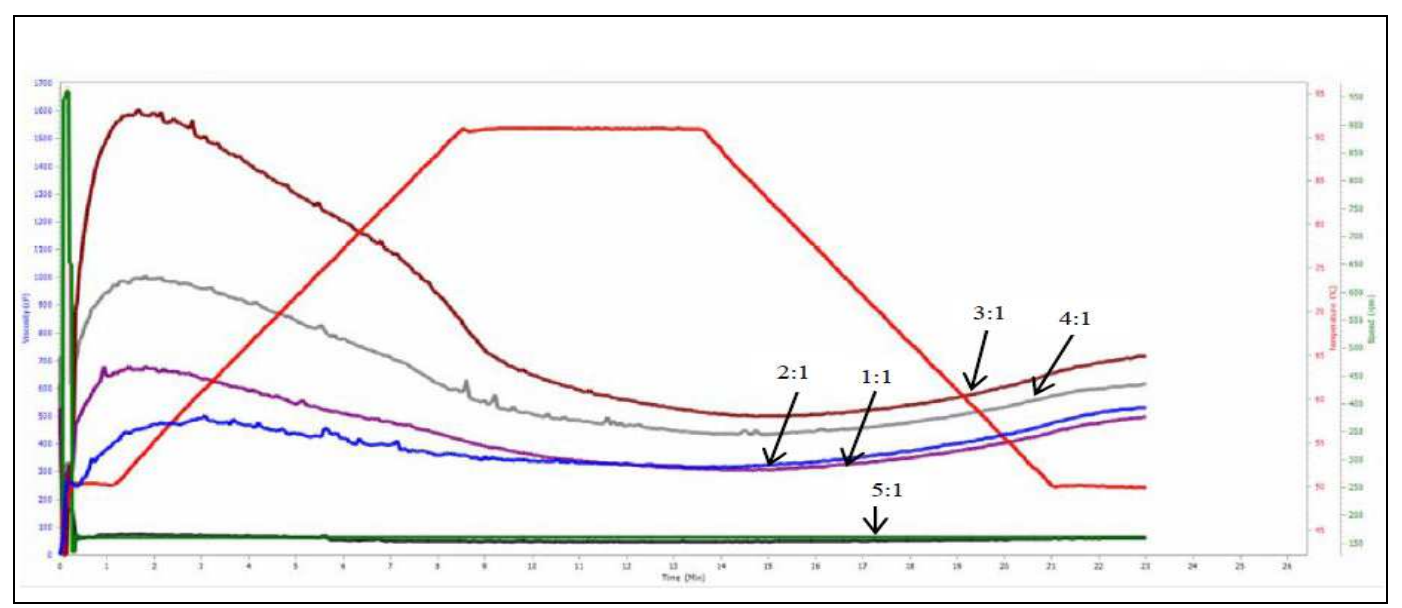

Fig. 2 Profile of RVA instant porridge made of pumpkin and arrowroot starch at treatment drum dryer with rotation speed at $1 \mathrm{rpm}$ 


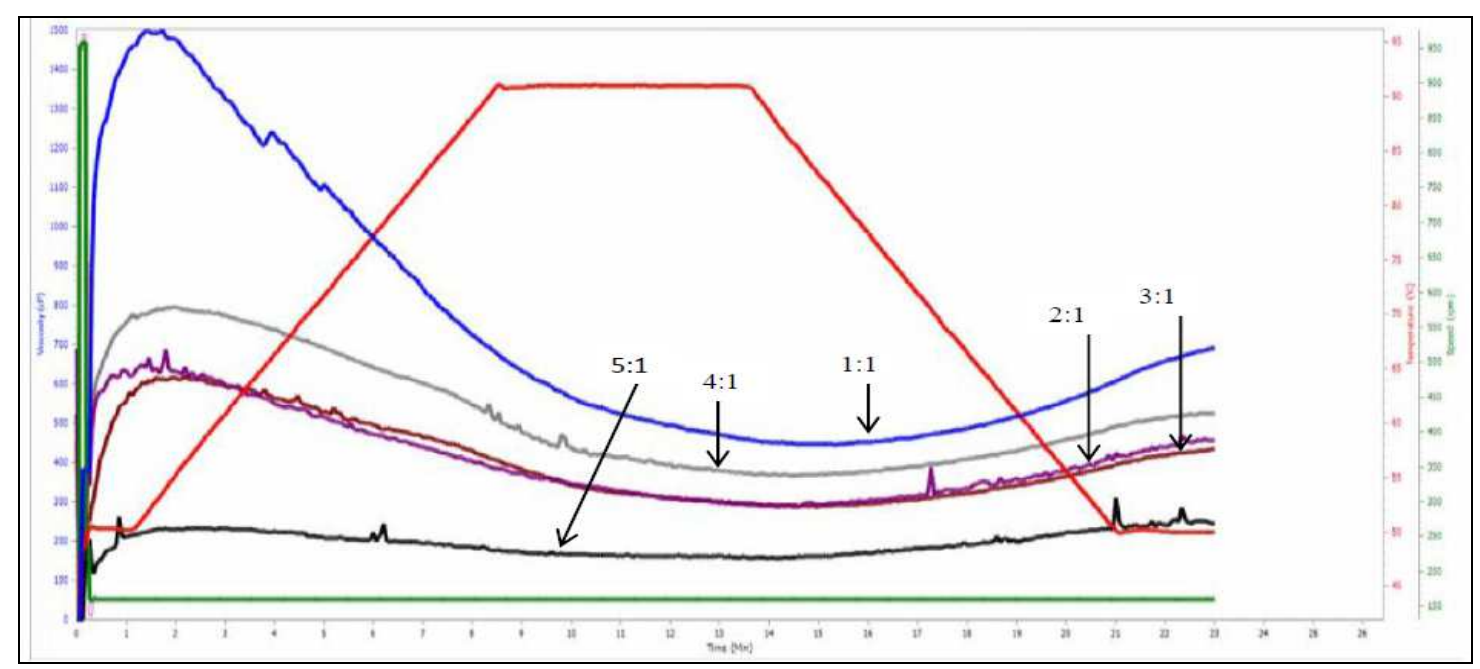

Fig. 3 Profile of RVA instant porridge made of pumpkin and arrowroot starch at treatment drum dryer with rotation speed at $1.5 \mathrm{rpm}$

1) Gelatinization Temperature: Table 4 shows that the gelatinization temperature was significantly different across treatments $(p<0.05)$, with a range between 50.07 and $89.7^{\circ} \mathrm{C}$. The gelatinization temperature of the raw material for instant porridge which consisted of pumpkin and arrowroot starch across treatments was $77.65-79.05^{\circ} \mathrm{C}$. It shows that the gelatinization temperature of the instant porridge is lower than that of the raw materials because of the heat during the cooking process in the drum dryer. High gelatinization temperature in treatment $4: 1$ and $5: 1$ at $1.5 \mathrm{rpm}$ rotation factor to the temperature was the composition of amylose, amylopectin, and fiber in the instant porridge. The temperature of the early gelatinization process was a phenomenon of complex physical properties of the starch which are affected by several factors such as the size of amylose and amylopectin molecules, and the heating media [50]. The treatment ratio of pumpkin and arrowroot starch at $1.5 \mathrm{rpm}$ rotation speed showed that the gelatinization temperature is higher than that at $1 \mathrm{rpm}$. It was because the starch composition decreased as the pumpkin proportion increased and contact with the drum dryer was longer at 1.5 $\mathrm{rpm}$ than $1 \mathrm{rpm}$ rotation speed. The instant porridge yield in treatment 5:1 at $1 \mathrm{rpm}$ rotation rate did not record gelatinization temperature due to the absence of paste forming: the higher the amylose level, the more solid gel consistency in rice starch [30]. Arrowroot starch has a high amylose level of around 28.03-31.34\% [33].

2) Peak Viscosity: Based on the result of the Rapid Visco Analyser, the treatment ratio of pumpkin and arrowroot starch affected the peak viscosity. Table 4 shows a significant difference in the peak viscosity of instant porridge $(\mathrm{p}<0.05)$. The peak viscosity of instant porridge ranged between 71.00 and 1,509.00 RVU, while the peak viscosity of the raw ingredients for porridge was 4,110.005,470.00 RVU. The considerable different peak viscosity of instant porridge and the raw ingredients was because the instant porridge had undergone heat treatment during the process in the drum dryer. The peak viscosity of treatment ratio 5:1 with rotation speed at 1 and $1.5 \mathrm{rpm}$ showed a highly significant difference. It was due to the different contact duration of pumpkin-arrowroot starch slurry with the drum dryer during the process. The slurry mixture had longer contact at $1.5 \mathrm{rpm}$ rotation speed than that at $1 \mathrm{rpm}$. Heat treatment to starch affected viscosity. Cooking duration stimulated interaction between amorph and crystalline areas. This interaction would increase the solidity of the starch molecule; therefore, starch penetration decreased, and the limited starch granule swelling caused the decrease of peak viscosity [56]. The peak viscosity is correlated with the swelling starch power and the damage of starch granule [33]. The decreasing peak viscosity in noodles substituted with rice starch was affected by starch swelling [31].

3) Trough Viscosity: Table 4 shows that trough viscosity showed a significant difference $(\mathrm{p}<0.05)$. Trough viscosity is the viscosity when the temperature stabilizes at $95^{\circ} \mathrm{C}$ for 10 minutes. Heating for 10 minutes made the starch granule fragile and damaged; therefore, it decreased the viscosity. Trough viscosity of instant porridge ranged between 48.00 and 498.00. The lowest viscosity (48.00 RVU) was obtained in instant porridge with 5:1 pumpkin and arrowroot starch ratio with a rotation speed at $1 \mathrm{rpm}$. The highest viscosity (498.00 RVU) was obtained in ratio 3:1 with rotation speed at $1 \mathrm{rpm}$. Trough viscosity shows the frailty of broken starch granule due to heating. A starch granule is more prone to damage and swelling due to the diminishing level of amylose [57]. Trough viscosity of instant porridge ranged between 48.00 and 498.00 RVU. The main ingredients of instant porridge showed trough viscosity between $4,110.00$ and 5,470.00 RVU. The decreasing trough viscosity in the main ingredients and the instant porridge is due to the heating process while cooking the instant porridge.

4) Breakdown Viscosity: Breakdown viscosity is related to starch granule being prone to heating and stirring. Low breakdown viscosity leads to low hydration and swelling power [31]. The main ingredients of instant porridge showed breakdown viscosity between 2,242.00 and 2,612.00 RVU [40]. Breakdown viscosity of instant porridge is lower than that of the main ingredients. The cooking process of instant porridge lowered the breakdown viscosity due to heating which changed the starch granule through the gelatinization process.

5) Setback Viscosity: Setback viscosity presented in Table 4 shows a significant difference $(\mathrm{p}<0.05)$. Setback viscosity shows the potential gelatinization and tendency to 
retrogradation. The result of the research shows that the setback viscosity value was 17.00-217.67 RVU. The setback viscosity of the main ingredients of instant porridge was 13 217.67 RVU. The different value of setback viscosity in the main ingredients and instant porridge was due to heating during porridge making. Setback viscosity value is used to determine retrogradation tendency and syneresis [58].

6) Final Viscosity: Table 4 shows that the final viscosity of instant porridge is significantly different $(\mathrm{p}<0.05)$ in a range of 61.67 and $619.00 \mathrm{RVU}$. The treatment ratio of 5:1 pumpkin and arrowroot starch with a rotation speed at $1 \mathrm{rpm}$ show the lowest value of final viscosity (61.67 RVU). It was because the treatment did not produce a paste. Final viscosity is an important factor to determine the characteristics of starch and to indicate the paste stability against heat during processing [33]. Protein and starch form a complex compound with granule surface and decrease the viscosity of starch. The lower viscosity would result in a lower gelatin power [31].

7) Peak Time: Peak time for instant porridge was 3.066.20 minutes. Peak time refers to the time needed for the

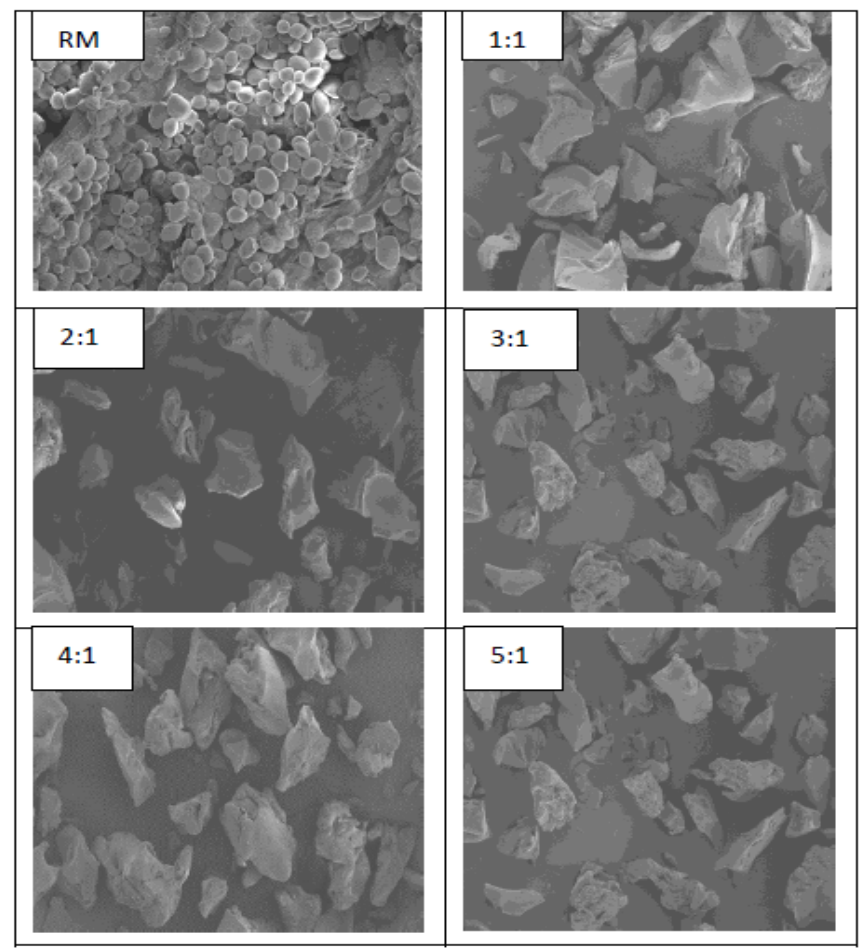

Fig. 4 The structure of starch granule instant porridge made of pumpkin and arrowroot starch at treatment drum dryer with rotation speed at $1 \mathrm{rpm}$ $\mathrm{RM}=$ row material

The starch granules in all treatment ratios of the pumpkin: arrowroot starch and treatment rotation speed were observed using Scanning Electron Microscopy. The shape of the starch granule of the main ingredients is round. It is different from that of the instant porridge because the starch granule of instant porridge had undergone gelatinization; therefore, the starch granule was broken and swollen. The treatment of drum dryer speed at 1 and $1.5 \mathrm{rpm}$ showed a different effect on the same ratio of pumpkin and starch. It was because, at $1.5 \mathrm{rpm}$ rotation speed, the ingredients had longer contact with the drum dryer; therefore, the starch was completely starch to form gelatine. The longest peak time was observed in treatment pumpkin: arrowroot starch 5:1 with rotation speed at $1.5 \mathrm{rpm}$. Starch gelatinization time is affected by the level of starch, particularly amylose [29]. The starch peak time of the main ingredients for instant porridge was 7.077.60 minutes. The process of making instant porridge can shorten the starch gelatinization time. A short time for starch gelatinization is needed to prepare instant porridge before serving.

Based on the description of the amylograph properties of instant porridge, it is evidenced that instant porridge had a type $\mathrm{C}$ amylograph profile. Type $\mathrm{C}$ amylograph profile can form paste-like sauce and porridge (instant or traditional). Instant porridge yielded from this research could form a paste, except for treatment pumpkin: arrowroot starch 5:1 with rotation speed at $1 \mathrm{rpm}$.

\section{E. Photomicroscopy of the Starch Granules of Instant Porridge}

The shape of the starch granules of the main ingredients and the instant porridge is presented in Fig. 4 and 5.

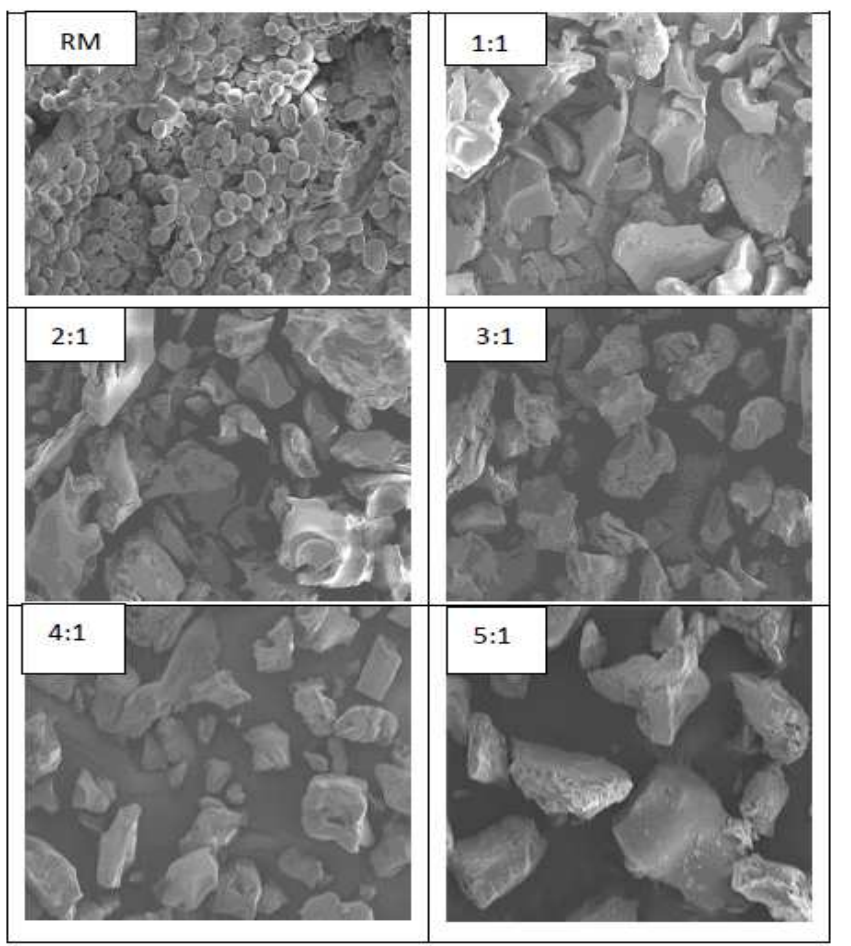

Fig. 5The structure of starch granule instant porridge made of pumpkin and arrowroot starch at treatment drum dryer with rotation speed at $1.5 \mathrm{rpm}$ $\mathrm{RM}=$ row material

gelatinized. With a constant water content, the increasing temperature and time would lead to the increasing size of the cavity in the starch granule. The changing shape of the starch granule would not occur when the heating was conducted at low heat or low water content [60].

\section{F. Acceptability of Instant Porridge}

The Hedonic scale of instant porridge on the color, aroma, flavor, consistency and overall evaluation are presented in Table 5 . 
TABLE V

HEDONIC SCALE OF PUMPKIN AND ARROWROOT STARCH INSTANT PORRIDGES

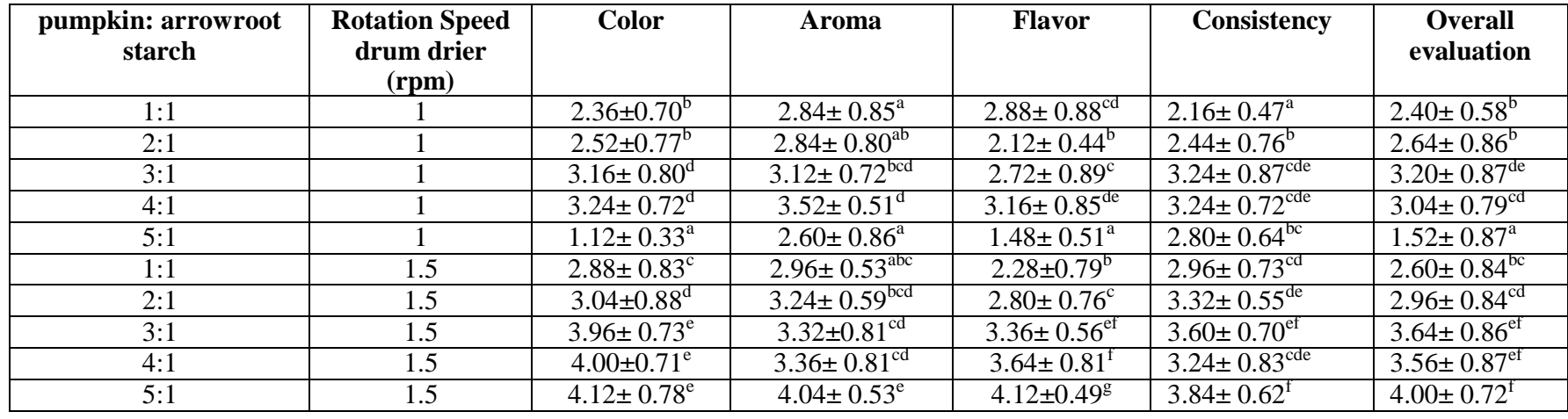

1) Color: Table 5 shows that the hedonic scale of the color of the instant porridge ranged between 1.12-4.12 (really dislike to like). The treatment of pumpkin and arrowroot starch $3: 1$ to $4: 1$ with drum dryer rotation speed produced instant porridge with favorable color. The higher pumpkin proportion, the more solid the orange color of the instant porridge. Orange color in pumpkin is derived from carotenoid [12]. The study of pumpkin powder dried at $60^{\circ} \mathrm{C}$ with drum dryer rotation speed at $6 \mathrm{rpm}$ showed a hedonic scale from really dislike to neutral [61]. The most disliked color of instant porridge yielded in this study was obtained from the treatment of pumpkin and arrowroot starch 5:1 with a rotation speed at $1 \mathrm{rpm}$. It was because the color of the instant porridge was less vibrant. The change of color was due to a browning non enzymatic reaction, oxidation and $\beta$ carotene isomerization [62]. In a study using cookies supplemented with $20 \%$ pumpkin flour, the yield color was redder than that with less than $20 \%$ supplementation [63].

2) Aroma: The aroma of instant porridge based on the hedonic scale was 2.60-4.04 (dislike to like). Table 5 shows that the higher the pumpkin proportion, the more favorable the aroma of instant porridge, except for treatment 5:1 with rotation speed at $1 \mathrm{rpm}$. The more pumpkin used, the more authentic and fresh the aroma of instant porridge; therefore, the aroma is more favorable. A study on cookies substituted with $20 \%$ pumpkin flour had a more favorable aroma than that cookies without pumpkin flour substitution [63]. Substituting $30 \%$ pumpkin flour in noodles resulted in the more preferred aroma [64].

3) Flavor: Table 5 shows that acceptability for instant porridge has a similar trend to aroma because the flavor is correlated with the aroma. Food with a preferable aroma was generally an acceptable product. Noodle substituted with $30 \%$ pumpkin flour had flavor that was palatable to the panelists [64].

4) Consistency: The hedonic scale on the consistency parameter shows that the higher the pumpkin proportion, the less preferable the consistency. The instant porridge's consistency would decrease as the component of starch diminished. Starch plays a role in the gelatinization process to form a gel and make the food consistent. The hedonic scale of noodle stickiness decreased as the substitution of pumpkin flour was increased [64]. Arrowroot starch is less stable with heating treatment as shown from the gelatinization profile that indicates high viscosity peak and a significant decrease of viscosity [32].
5) Overall evaluation. Table 5 shows that the overall acceptability of instant porridge ranged between 1.52 and 4.00 (really dislike to like). The highest overall acceptability of instant porridge was derived from treatment pumpkin and arrowroot starch 5:1 with rotation speed at $1.5 \mathrm{rpm}$. Substituting $20 \%$ pumpkin flour to noodles based on the hedonic scale for overall evaluation was not significantly different from noodle without pumpkin [64]. Biscuits substituted with $2.5 \%$ pumpkin flour showed overall acceptability according to panelists [24]. Similarly, cake with $20 \%$ pumpkin flour substitution was acceptable overall to the panelists [21].

The best and most acceptable instant porridge according to the panelists was obtained from ratio 5:1 for pumpkin and arrowroot starch with rotation speed at $1.5 \mathrm{rpm}$. Chemical analysis was conducted to investigate the level of $\beta$ carotene, antioxidant activity, phenol, starch resistant, fiber, insoluble fiber and energy. The result of the analysis showed that the porridge contained $3,422.48 \mu \mathrm{g} / 100 \mathrm{~g} \beta$ carotene, $46.42 \%$ antioxidant activity, $0.06 \%$ phenol, $0.19 \%$ starch resistant, $11.97 \%$ fiber, $11.28 \%$ insoluble fiber, $1.33 \%$ soluble fiber, and $291.86 \mathrm{Cal} / 100 \mathrm{~g}$ energy.

\section{CONCLUSIONS}

Treatment ratio pumpkin: arrowroot starch and the rotation speed of the drum dryer affected the physicochemical properties and acceptability of the instant porridge yield in this study. The best and most preferred instant porridge according to panelists was obtained from treatment pumpkin: arrowroot starch with rotation speed at $1.5 \mathrm{rpm}$. The physical properties of instant porridge included $15.84 \%$ yield; $0.27 \mathrm{~g} / \mathrm{ml}$ bulk density; $12.38 \mathrm{~g}$ water $/ \mathrm{g}$ WHC; $0.37 \mathrm{~g}$ oil $/ \mathrm{g}$ OHC; $36.98 \%$ solubility; and 8,233.00 cP viscosity. The chemical properties included $5.52 \%$ water; $2.74 \%$ ash; $2.54 \%$ fat; $4.57 \%$ protein; $31.52 \%$ starch; $19.11 \%$ amylose; $80.89 \%$ amylopectin; $83.64 \%$ carbohydrate; $46.42 \%$ antioxidant activity; 3,422.48 $\mu \mathrm{g} / 100$ g $\beta$ carotene; $0.06 \%$ phenol; $0.19 \%$ resistant starch; $11.97 \%$ fiber; $11.28 \%$ insoluble fiber; $1.33 \%$ soluble fibre and $291.86 \mathrm{Cal} / 100 \mathrm{~g}$ energy. The amilograph characteristics of instant porridge consisted of a gelatinization temperature at $76.84^{\circ} \mathrm{C} ; 245.00 \mathrm{RVU}$ peak viscosity; $157.33 \mathrm{RVU}$ trough; 88.00 RVU breakdown viscosity; 88.67 RVU setback viscosity; 342.33 RVU final viscosity and peak time 6.20 minutes. The granule of the instant porridge is bigger and open. 


\section{ACKNOWLEDGMENTS}

This research is fully supported by using the scholarship funds of the Government of the Republic of Indonesia through the Indonesian Institute of Education Scholarship Fund Management Institution (LPDP BUDI-DN) Indonesia. Number: PRJ-4952/LPDP.3/2016

\section{REFERENCES}

[1] G. Neelamma, B.D. Swamy, and P. Dhamodaran, "Phytochemical and Pharmacological Overview of Cucurbita maxima and future Perspective as Potential Phytotherapeutic Pgent." European J Pharm Med Res, vol. 3, pp. 277-287, 2016.

[2] S. Patel, and A. Rauf, "Edible seeds from Cucurbitaceae family as potential functional foods: Immense promises," few concerns. Biomedicine and Pharmacotherapy, vol. 91, pp. 330-337, 2017.

[3] M. Murkovic, U. Mulleder, and H. Neunteufl, "Carotenoid content in different varieties of pumpkins." Journal of Food Composition and Analysis vol. 15, pp. 633-638, 2002

[4] J. Song, Q. Wei, X.Wang, D. Li, C.Liu, M. Zhang, and L. Meng, "Degradation of carotenoids in dehydrated pumpkins as affected by different storage conditions.” Food Research International, vol. 107, pp.130-136, 2018.

[5] P. Wang, J.C. Liu, and Q.Y. Zhao, "Studies on nutrient composition and utilization of pumpkin fruit." Journal of Inner Mongolia Agricultural University, vol. 23, pp. 52-54, 2002.

[6] M. F. de Escalada Pla, N. M. Ponce, C. A. Stortz, L. N. Gerschenson, and A.M. Rojas, "Composition and functional properties of enriched fiber products obtained from pumpkin (Cucurbita moschata Duchesne ex Poiret)." LWT-Food Science and Technology, vol 40 no.7, pp. 1176-1185, 2007.

[7] V. N. Jacobo, Z.M.J. de Jesus, I. J. A. Gallegos, G,F. Aguilar H.I.L. Camacho, G.N.E. Rocha, and L.R.F. Gonzalez "Chemical and physicochemical characterization of winter squash (Cucurbita moschata D.)". Notulae Botanicae Horti Agrobotanici Cluj-Napoca, vol. 39, no.1, pp. 34-40, 2011.

[8] F. L. Hong, J. Lui, W.B. Peng, and H.W. Chiu, "Investigation on the Physicochemical Properties of Pumpkin Flour (Cucurbita moschata) Blend with Corn by Single-Screw Extruder." Journal of food processing and preservation, vol. 39, no.6, pp. 1342-1354, 2015.

[9] L. Liang, L. Ao, T. Y.Y. Ma, X.J. Ni, X.S. Liao, Y. Hu, and Song, "Sulfated modification and anticoagulant activity of pumpkin (Cucurbita pepo, Lady Godiva) polysaccharide," Int. J.Biol. Macromol. 106: 447-455. 2018.

[10] W.X. Shen, C.H. Chen, Y.Y. Guan, X.W. Song, Y.H. Jin, J.F. Wang, Y.T. Hu, Q.Y. Xin, L. Jiang, and A. Zhong, "Pumpkin Polysaccharide Induces Apoptosis by Inhibiting The JAK2/STAT3 Pathway in Human Hepatoma HepG2 Cells". Int. J. Biol. Macromol. Vol. 104, pp. 681-686, 2017.

[11] I. Dini, G. C. Tenore, and A. Dini, "Effect of industrial and domestic processing on antioxidant properties of pumpkin pulp." LWT-Food Science and Technology, vol. 53, no.1, pp. 382-385, 2013.

[12] J.G. Provesi, C.O. Dias, and E. R. Amante, "Changes in carotenoids during processing and storage of pumpkin puree." Food Chemistry, vol. 128 , no. 1 , pp. 195-202, 2011.

[13] G. Liu, L.Liang, G.Yu, and Q. Li, "Pumpkin polysaccharide modifies the gut microbiota during alleviation of type 2 diabetes in rats". International Journal of Biological Macromolecules, vol. 115, pp. 711-717, 2018

[14] L. Chen, and G. Huang, "Antioxidant activities of phosphorylated pumpkin polysaccharide." International journal of biological macromolecules, vol. 125, pp. 256-261, 2018.

[15] Y. Listianasari, P. Dirgahayu, B. Wasita, and. M.P.A Nuhriawangsa, "Efektifitas Pemberian Jus Labu Siam (Sechium Edule) Terhadap Profil Lipid Tikus (Rattus Novergicus) Model Hyperlipidemia". Penelitian Gizi dan Makanan (The Journal of Nutrition and Food Research), vol. 40, no. 1, pp. 35-43, 2017.

[16] A.G. Agrawal, and R.N. Methekar, "Mathematical model for heat and mass transfer during convective drying of pumpkin." Food Bioprod. Process, vol. 101,pp. 68-73, 2017.

[17] A. Nawirska-Olszanska, B. Stepien, and A. Biesiada, "Effectiveness of the fountain-microwave drying method in some selected pumpkin cultivars." LWT- Food Science and Technology, vol. 77, pp. 276281, 2017.
[18] L. Seremet, E. Botez, O.V. Nistor, D.G. Android, and G.D. Mocanu, "Effect of different drying methods on moisture ratio and rehydration of pumpkin slices." Food Chem, vol. 195, pp. 104-109, 2016.

[19] Song, J., Wang, X., Li, D., Meng, L., and Liu, C. "Degradation of carotenoids in pumpkin (Cucurbita maxima L.) slices as influenced by microwave vacuum drying." Int. J. Food Prop, vol. 20, no.7, pp. 1479-1487, 2017.

[20] E. Aydin, and D. Gocmen, "The influences of drying method and metabisulfite pretreatment on the color, functional properties, and phenolic acids contents and bioaccessibility of pumpkin flour." LWT - Food Science and Technology, vol. 60, no. 1, pp. 385-392, 2015.

[21] K. S. Mala, P. Aathira, E.K. Anjali, K. Srinivasulu, and G. Sulochanamma, "Effect of pumpkin powder incorporation on thephysicochemical, sensory and nutritional characteristics of wheat flour muffins.” International Food Research Journal, vol. 25, no.3, pp. 1081-1087, 2018.

[22] V. T. T. Đào, "Optimization of drum drying process parameters for pumpkin powder production and its substitution in rice noodles." Journal of Science, vol. Three no. 3, pp.149 - 160, 2015.

[23] N. L. Tanpubolon, K.K. Terip, and Ridwansyah. "Formulasi Bubur Bayi Instan dengan Substitusi Tepung Tempe dan Tepung Labu Kuning sebagai Alternatif Makanan Pendamping ASI". J.Rekayasa Pangan dan Pert., vol. 2, no. 2, pp. 78-83, 2014.

[24] Kulkarni, A. S., and Joshi, D. C. "Effect of replacement of wheat flour with pumpkin powder on textural and sensory qualities of a biscuit." International Food Research Journal, vol. 20, no. 2, pp. 587591, 2013.

[25] A. H. Aljahani, and A. N. Al-Khuarieef, "Effect of Mixing Wheat Flour with Pumpkin and Dates on the Nutritional and Sensory Characteristics of Cake." Pakistan Journal of Nutrition, vol. 16, no. 4, pp. 273-278, 2017.

[26] Dyshlyuk, L., Babich, O., Prosekov, A., Ivanova, S., Pavsky, V., and Yang, Y. In vivo study of medical and biological properties of functional bakery products with the addition of pumpkin flour. Bioactive carbohydrates and dietary fiber, vol. 12, pp. 20-24, 2017.

[27] C. A. Romero-Bastida, L. A. Bello-Pérez, G. J. Velazquez, and J. Alvarez-Ramirez, "Effect of the addition order and amylose content on the mechanical, barrier and structural properties of films made with starch and montmorillonite." Carbohydrate Polymers, vol. 127, pp. 195- 201, 2015.

[28] F.Villas-Boas, and C. M. L. Franco, "Effect of bacterial b-amylase and fungal amylase on the digestibility and structural characteristics of potato and arrowroot starches." Food Hydrocolloids, vol. 52, pp. 795-803, 2016.

[29] R. M., Astuti, N. Asiah, A. Setyowati, and R. Fitriawati, "Effect of physical modification on granule morphology, pasting behavior, and functional properties of arrowroot (Maranta arundinacea L) starch." Food Hydrocolloids, vol. 81, pp. 23-30, 2018.

[30] Photoset, S. and S. Charoenrein. "Morfologi and physicochemical changes in rice flour during rice paper production," Food Research International vol. 40, pp. 266-272, 2007.

[31] S. Srichuwong, T. C. Sunarti, T. Mishima, N. Isono, and M. Hisamatsu, "Starches from different botanical sources I: Contribution of amylopectin fine structure to thermal properties and enzyme digestibility." Carbohydrate Polymers, vol. 60, no. 4, pp. 529-538, 2005.

[32] D. N. Faridah, D. Fardiaz, N. Andarwulan, and T. C. Sunarti, "Karakteristik sifat fisikokimia pati garut (Maranta arundinaceae)". Agritech, vol. 34, no. 1, pp. 14-21, 2014.

[33] A. L. Charles, K. Cato, T. Huang, Y. Chang, J. Ciou, and J. Chang, Functional properties of arrowroot starch in cassava and sweet potato composite starches. Food Hydrocolloids, vol. 30, pp. 1-5, 2016.

[34] G. F. Nogueira, F. M. Fakhouri, and R. A. de Oliveira, "Extraction and characterization of arrowroot (Maranta arundinaceae L.) starch and its application in edible films." Carbohydrate Polymers, vol. 186, pp. 64-72, 2018.

[35] A. Mišan, A. Petelin, M. Stubelj, A. Mandić, Šimurina, O. M. Pojić, and Z. J. Pražnikar, "Buckwheat-enriched instant porridge improves lipid profile and reduces inflammation in participants with mild to moderate hypercholesterolemia." Journal of Functional Foods, vol. 36, pp. 186-194, 2017.

[36] T. Rakcejeva, R. Galoburda, L. Cude, and E. Strautniece, "Use of dried pumpkins in wheat bread production." Procedia Food Science, vol. 1, pp. 441-447, 2011.

[37] P. Hariyadi, "Pengering Drum: Cocok untuk pengembangan produk bubur instan". FoodReview Indonesia, vol. X, no 5, pp. 45-49, 2015. 
[38] H. Sabarez, Drying of Food Materials CSIRO Food and Nutrition, Werribee, VIC, Australia. 2015

[39] P. Galaz, M. Valdenegro, C. Ramírez, H. Nuñez, S. Almonacid, and R. Simpson, "Effect of drum drying temperature on drying kinetic and polyphenol contents in pomegranate pee." Journal of food engineering, vol. 208, pp. 19-27, 2017.

[40] AOAC. Official methods of analysis of AOAC international. 18th ed. Washington: Association of Official Analytical Chemists. 2007.

[41] A. Juliano. "Simplified Assumy for milled rice Amylose." Cereal Sci. Today, vol. 16, pp. 34-39, 1971

[42] Hustiyani. "Modifikasi asilasi dan suksinilasi pati tapioka sebagai bahan enkapsulasi komponen flavor". Disertasi sekolah pascasarjana Institut Pertanian Bogor, Bogor. 2006

[43] F. Que, L. Mao, X. Fang, and T. Wu, "Comparison of hot air-drying and freeze-drying on the physicochemical properties and antioxidant activities of pumpkin (Cucurbita moschata Duch.) flours". International journal of food science and technology, vol. 43, no. 7, pp. 1195-1201, 2008

[44] A. M. Goula, K. G. Adamopoulos, and N. A. Kazakis, "Influence of spray drying conditions on tomato powder properties." Drying Technology, vol. 22, no. 5, pp. 1129- 1151, 2004.

[45] AACC. Approved methods of the AACC, (10th edn). Association of Official Analytical Communities, Maryland, USA. 2000.

[46] C. L. Zhou, L. Mi, X. Y. Hu, and B. H. Zhu, "Evaluation of three pumpkin species: correlation with physicochemical, antioxidant properties and classification using SPME-GC-MS and E-nose methods." Journal of food science and technology, vol. 54, no. 10, pp. 3118-3131, 2017.

[47] H. Danilchenko, E. Jarenie, A. Paulauskiene, J. Kulajtiene, and P. Viskelis, "Effect of fertilization on the quality and chemical composition of pumpkin.” Annales UMCS Sec, vol. E 59, pp. 19491956,2000

[48] N. Rif'an, and A. Siti. "Pengaruh Jenis Alat Pengering Terhadap Karakteristik Fisik, Kimia dan Organoleptik Sup Labu Kuning Instan". JURNAL PANGAN DAN GIZI, vol.7, no. 2, pp. 104-116, 2017

[49] W. Roongruangsri, and J.E. Bronlund, "Effect of air-drying temperature on physicochemical, powder properties and sorption characteristics of pumpkin powders." International Food Research Journal, vol. 23, no. 3, pp. 962-972, 2016.

[50] V. Vamadevan, and E. Bertoft, "Impact of different structural types of amylopectin on retrogradation." Food Hydrocolloids, vol. 80, pp. $88-96,2018$

[51] S. L. Chia, and G. H. Chong, "Effect of rotation speed and steam pressure on physicochemical properties of drum dried pitaya (Hylocereus polyrhizus) peel." International Food Research Journal, vol. 22 , no. 1 , pp. 272-276, 2015.

[52] R. S. Al-Mukhtar, "Effect of Feed Concentration on the Production of Pregelatinized Starch in a Double Drum Dryer." Iraqi Journal of Chemical and Petroleum Engineering, vol, 8, no, 13-17, 2007.
[53] D. Junita, B. Setiawan, F, Anwar, and T. Muhandri, "Komponen gizi, aktivitas antioksidan dan karakteristik sensori bubuk fungsional labu kuning (Cucurbita moschata) dan tempe". Jurnal Gizi dan Pangan, vol. 12, no. 2, pp. 109-116, 2017.

[54] Standar Nasional Indonesia, Badan Standarisasi Nasional Indonesia. SNI 01-7111.1-2005.

[55] B. Shafie, S. C, Cheng, H. H. Lee, and P. H. Yiu, "Characterization and classification of whole-grain rice based on rapid visco analyzer (RVA) pasting profile." International Food Research Journal, vol. 23 no. 5.pp. 2138-2149, 2016.

[56] Y. Pranoto, Rahmayuni, Haryadi and S. K. Rakshit, "Physicochemical properties of heat-moisture treated sweet potato starches of selected Indonesian varieties." International Food Research Journal, vol. 21, no. 5, pp. 2031-2038, 2014.

[57] A. Kaur, N. Singh, R. Ezekiel, and H.S. Guraya, "Physicochemical, Thermal and Pasting Properties of Starches Separated from Different Potato Cultivars Grown at Different Locations." Food Chemistry, vol. 101, no. 2, pp. 643-651, 2007.

[58] K.O. Adebowale, B.I.O, Owolabi, E.K. Olawumi, and O.S. Lawal, "Functional properties of native physically and chemically modified breadfruit (Artocarpus articles) starch." Industrial Crops and Products, vol. 21, pp. 343-351, 2005.

[59] E. Syamsir, P. Hariyadi, D. Fardiaz, N. Andarwulan, and F. Kusnandar, "Pengaruh proses heat-moisture treatment (HMT) terhadap karakteristik fisikokimia pati [Effect of Heat-Moisture Treatment (HMT) Process on Physicochemical Characteristics of Starch].” Jurnal Teknologi dan Industri Pangan, vol. 23, no. 1, pp. 100-106, 2012.

[60] M. Tsakama, A.M. Mwangwela, T.A. Manani, and N.M. Mahungu, "Effect of heat-moisture treatment on physicochemical and pasting properties of starch extracted from eleven sweet potato varieties". International Research Journal of Agricultural Science and Soil Science, vol. 1, no. 7, pp. 254-260, 2011.

[61] S. Usmiati, O. Maria, S. Yuliani, Purwani, and E. Y. D. Setyaningsih, "Karakteristik serbuk labu kuning (Cucurbita moschata) [Characteristic of Pumpkin Powder (Cucurbita moschata)]". Jurnal Teknologi dan Industri Pangan, vol. 16, no. 2, pp. 157-167, 2005.

[62] P. E. Camorani, L. Chiavaro, M. Cristofolini, M. Paciulli, A. Zaupa, Visconti, and N. R. Pellegrini, "Spectroscopy application in frozen carrot cooked in different ways and the relationship with carotenoids". Journal of the Science of Food and Agriculture, vol. 95 no. 11 , pp. 2185-2191, 2015.

[63] S. H. Hosseini Ghaboos, Seyedain S. M. Ardabili, and M Kashaninejad, "Physico-chemical, textural and sensory evaluation of sponge cake supplemented with pumpkin flour." International Food Research Journal, vol. 25, no. 2, pp. 854-860, 2018.

[64] N. Aukkanit, and Sirichoworrakit, "Effect Dried Pumpkin Powder on Physical, Chemical, And Sensory Properties of Noodle." International Journal of Advances in Science Engineering and Technology, vol. 5, no. 1, pp. 14-18, 2017. 